\title{
PERSEPSI TENTANG MANFAAT SENAM YOGA TERTAWA TERHADAP KESEHATAN LANSIA DI KOTA DENPASAR
}

\author{
I Kadek Abdi Kesuma Wijaya*, Ni Komang Ekawati, Ni Wayan Arya Utami \\ Program Studi Kesehatan Masyarakat Fakultas Kedokteran Universitas Udayana \\ *Email:abdi_kesuma@rocketmail.com
}

\begin{abstract}
ABSTRAK
Lanjut usia menurut definisi dari World Health Organization (WHO) adalah orang yang berusia 60 tahun keatas. Lansia sangat rentan untuk terkena penyakit. Beberapa penyakit yang dialami oleh lansia adalah hipertensi, rematik, diabetes mellitus, gagal jantung dan lain-lain. Selain upaya penanganan kesehatan yang dibuat pemerintah, terdapat kegiatan lain yang dapat menangani masalah kesehatan pada lansia yaitu senam yoga tertawa. Penelitian ini bertujuan untuk mengetahui persepsi tentang manfaat senam yoga tertawa terhadap kesehatan lansia di Kota Denpasar.Penelitian ini merupakan penelitian kualitatif dengan menggunakan pendekatan fenomenologi yang menggunakan metode pengumpulan data dengan Focus Group Discussion dan wawancara mendalam. Berdasarkan hasil penelitian, sebagian besar lansia memandang di usia 60 tahun keatas akan rentan terkena penyakit serius. Lansia yang mengikuti senam yoga tertawa didorong atas 2 faktor yaitu faktor internal dikarenakan ingin sembuh dan menjadi lebih sehat, serta faktor eksternal disebabkan oleh dukungan keluarga. Tidak ada hambatan yang dirasakan lansia dalam mengikuti senam yoga tertawa. Hal ini dikarenakan mereka termotivasi untuk sehat dan sembuh dari penyakit serta dukungan dari keluarga.Kesimpulan bahwa persepsi lansia terhadap manfaat senam yoga tertawa adalah sakit yang dirasakan berkurang dan lebih sehat. Jadi dapat disarankan senam yoga tertawa dapat diterapkan sebagai alternatif untuk membantu lansia dalam mengatasi masalah kesehatan dan bagi penelitian selanjutnya dapat dijadikan dasar penelitian dalam hal kesehatan lansia dan yoga.
\end{abstract}

Kata Kunci: persepsi, senam yoga tertawa, lansia, kesehatan mental, Denpasar

\begin{abstract}
The elderly according to the definition of the World Health Organization (WHO) are people aged 60 years and over. The elderly are very susceptible to disease. Some diseases experienced by the elderly are hypertension, rheumatism, diabetes mellitus, heart failure and others. In addition to health care efforts made by the government, there are other activities that can handle health problems in the elderly, namely laughing yoga exercises. This study aims to determine perceptions about the benefits of laughing yoga exercises on the health of the elderly in Denpasar City. This research is a qualitative study using a phenomenological approach that uses data collection methods with Focus Group Discussion and in-depth interviews. Based on the results of the study, most of the elderly looked at the age of 60 years and over will be vulnerable to serious illness. The elderly who attend yoga exercises are encouraged to push for 2 factors: internal factors due to wanting to recover and become healthier, and external factors caused by family support. There are no obstacles felt by the elderly in participating in the laughing yoga exercises. This is because they are motivated to be healthy and recover from illness and support from the family. The conclusion that the elderly's perception of the benefits of laughing yoga is a pain reduction and healthier. So it can be suggested laughing yoga exercises can be applied as an alternative to helping the elderly in overcoming health problems and for further research can be used as a basis for research in terms of health of the elderly and yoga.
\end{abstract}

Keywords: perception, laughing yoga exercises, elderly, mental health, Denpasar

\section{PENDAHULUAN}

Lanjut usia menurut definisi dari

World Health Organization (WHO) adalah orang yang berusia 60 tahun keatas. Secara global pada tahun 2013 proporsi dari populasi penduduk berusia lebih dari 60 tahun adalah $11,7 \%$ dari total populasi dunia dan diperkirakan akan meningkat seiring dengan peningkatan harapan hidup. Data WHO menunjukan pada tahun 2000 usia harapan hidup orang di dunia 
adalah 66 tahun, dan pada tahun 2012 naik menjadi 70 tahun (WHO, 2015).

Indonesia adalah salah satu negara yang terletak di Asia Tenggara yang memasuki era penduduk berstruktur lansia (aging structured population). Peningkatan jumlah penduduk lansia ini disebabkan antara lain karena tingkat sosial ekonomi masyarakat yang meningkat, kemajuan di bidang pelayanan kesehatan, dan tingkat pengetahuan masyarakat yang meningkat. Berdasarkan sensus penduduk pada tahun 2010, jumlah lanjut usia di Indonesia yaitu 18,1 juta jiwa (7,6\% dari total penduduk). Pada tahun 2014, jumlah penduduk lanjut usia di Indonesia menjadi 18,781 juta jiwa dan diperkirakan pada tahun 2025, jumlahnya akan mancapai 36 juta jiwa.

Setiap manusia mengalami proses penuaan. Kemajuan ekonomi, pengetahuan dan teknologi terutama di bidang ilmu kesehatan, promosi kesehatan, pencegahan penyakit dan pelayanan kesehatan mengakibatkan meningkatnya usia harapan hidup manusia. Hal ini mengakibatkan pertambahan jumlah lansia akan meningkat dengan cepat (Azizah, 2011).

Semakin bertambah umur seseorang semakin banyak penyakit yang muncul dan sering diderita khususnya dialami pada lansia. Proses penuaan merupakan proses yang mengakibatkan perubahan-perubahan meliputi perubahan fisik, psikologis, sosial dan spiritual. Beberapa penyakit yang dialam oleh lansia diantaranya adalah hipertensi, rematik, diabetes mellitus, gagal jantung dan lain-lain. Terkait dengan kesehatan mental, setiap lansia akan mengalami gangguan psikologis. Gangguan psikologis adalah gangguan yang dialami individu dalam cara berpikir (cognitive), kemauan, emosi dan perilaku. Dalam mengatasi masalah kesehatan lansia, pemerintah telah berupaya untuk membuat program-program pelayanan kesehatan terhadap lansia. Pelayanan kesehatan lansia ini meliputi upaya promotif, preventif, kuratif dan rehabilitatif. Upaya promotif misalnya seperti kegiatan penyuluhan atau pemberian informasi berupa dorongan moral kepada lansia.

\section{METODE}

Penelitian ini menggunakan metode penelitian kualitatif. Penelitian ini menggunakan pendekatan fenomenologi, yaitu ilmu tentang esensi-esensi kesadaran dan esensi ideal dari objek-objek sebagai korelasi dengan kesadaran (Donny, 2005).

Pengumpulan data menggunakan pengumpulan data primer dengan cara yaitu Diskusi Kelompok Terarah atau FGD (Focus Group Discussion) dan wawancara mendalam (indepth interview).

Pada penelitian ini, peneliti melakukan analisis data berdasarkan tema-tema yang sesuai dengan kerangka konsep penulis, maka dalam penelitian ini digunakan metode analisis tematik.

\section{HASIL \& PEMBAHASAN}

Durasi mengikuti senam yoga tertawa

Berdasarkan hasi FGD didapatkan sebagian besar informan baik laki-laki maupun perempuan telah mengikuti senam yoga tertawa selama lebih dari 6 bulan. Sebagaimana pernyataan informan sebagai berikut :

"Tiyang ikut yoga tertawa niki sudah 9 bulan...(I-5)". "Tiyang ampun sue, ampun 32 bulan asane...(I-1)" 
Berdasarkan hasil penelitian informan percaya dengan 6 bulan mengikuti senam yoga tertawa akan memberikan dampak positif bagi kesehatan. Kondisi yang sama juga terjadi di Panti Werdha Luhur Sidoarjo. Dimana dari hasil penelitian (Trifonia, 2015) menunjukan lansia yang tinggal di panti selama 6 bulan dan telah mengikuti terapi tertawa merasakan efektifitas terapi tertawa terhadap penurunan tingkat depresi. Semakin rutin mengikuti senam yoga tertawa semakin besar manfaat yang dirasakan. Seperti yang terjadi di Panti UPTD Griya Wreda Surabaya.

$\underline{\text { Alasan mengikuti senam yoga tertawa }}$

Alasan informan mengikuti senam yoga tertawa adalah sebagian besar informan baik laki-laki maupun perempuan mengikuti senam yoga tertawa karena merasa sakit. Sebagaimana pernyataan informan sebagai berikut :

"Nah karena pada saat itu kebetulan saya sakit saya luar biasa komplikasi begitulah... (I-6)".

"Karena saya mempunyai keluhan sakit kepala...(II-1)"

Berdasarkan hasil FGD diketahui bahwa sebagian besar dari mereka menyatakan alasan mengikuti senam yoga tertawa karena sakit. Sakit yang dirasakan lansia seperti susah tidur, sakit kepala, cemas, hipertensi, jantung dan bingung. Mereka percaya bahwa senam yoga tertawa dapat menyembuhkan sakit yang mereka rasakan. Namun, tidak semua penyakit bisa disembuhkan dari senam yoga tertawa. Terapi tertawa dapat digunakan untuk membantu merawat pasien yang mengalami gangguan psikosomatis dan kondisi-kondisi negatif seperti depresi dan kecemasan. Hal ini dikarenakan ketika tertawa, otot-otot wajah akan bergerak membentuk ekspresi bahagia sehingga berpengaruh terhadap sistem saraf (Anggun, 2011).

\section{Sakit yang diderita sebelumnya}

Sakit yang diderita informan laki-laki sebelum mengikuti senam yoga tertawa adalah susah tidur, rasa cemas, beban pikiran, kesemutan, sakit jantung, dan asam urat. Dari keseluruhan, sebagian besar informan menyatakan sakit susah tidur. Sebagaimana pernyataan informan sebagai berikut :

"Pada waktu dulu tiyang puja laksmi dulu ya, setelah puja laksmi karena saya ingin ketemu sama temen-temen itu, akhirnya ikut juga senam yoga tertawa, dan saya juga permasalahanya, saya gak bisa tidur...(I-4").

Namun informan perempuan sebagian besar menyatakan sakit kepala. Sebagaiman pernyataan informan sebagai berikut :

"Saya cobak-cobak kesini, lihat-lihat dulu tapi belum langsung ikut. Yaa rasanya sih oke. Karena saya mempunyai keluhan sakit kepala...(II-1)"

Dari penyakit yang diderita lansia sebelum mengikuti senam yoga tertawa menunjukan hal yang sesuai dengan manfaat dari senam yoga tertawa. Sebagian besar informan laki-laki menyatakan sakit tidak bisa tidur. Sedangkan sebagian besar informan perempuan menyatakan sakit kepala atau pusing. Hal ini sesuai dengan manfaat senam yoga tertawa seperti dalam penelitian (Ika, 2014 ) pada usia lanjut di PSTW Yogyakarta Unit Budi Luhur, menunjukan bahwa sebagian besar lansia mengeluh kesulitan untuk memulai tidur. Rata-rata setelah diberi terapi tertawa responden mengungkapkan adanya 
penurunan keluhan gangguan tidur. Selain itu, pada penelitian (Esterina, 2011) menunjukan adanya pengaruh terapi tawa terhadap sakit kepala dan stres di Panti Werdha Hargo Dedali. Hal tersebut dikarenakan salah satu manfaat dari tertawa adalah menyembuhkan insomnia atau gangguan tidur dan sakit kepala.

Sumber informasi adanya senam yoga tertawa

Dari hasil penelitian didapatkan bahwa sebagian besar informan baik lakilaki maupun perempuan mendapatkan sumber informasi mengenai adanya senam yoga tertawa adalah dari teman dan televisi. Sebagaimana pernyataan informan sebagai berikut :

"Secara kronologis, awalnya sebenarnya saya tidak tahu ada kegiatan yoga tertawa ini. Ini kebetulan pada saat itu pada malam hari saya nonton to bersama istri memperhatikan ada wawancara di to ada acara bagus. Nah itu awalnya saya perhatikan dengan seksma rasanya ada kecocokan dalam hati...(I-6)"

"Akhirnya tiyang kesini, diajak temen...(II-2)"

Berdasarkan sumber informasi yang didapat tentang adanya senam yoga tertawa menunjukan bahwa sumber informasi memberikan dampak kecil terhadap alasan lansia mengikuti senam yoga tertawa. Karena alasan lansia mengikuti senam yoga tertawa lebih banyak dipengaruhi karena sakit. Sedangkan sebagian besar lansia menyatakan sumber informasi didapatkan dari teman. Dalam hal ini, sumber informasi memberikan pengaruh yang kecil terhadap alasan lansia melakukan tindakan sehat yakni mengikuti senam yoga tertawa.

\section{Persepsi keseriusan penyakit}

Keseriusan penyakit yang dirasakan informan baik laki-laki maupun perempuan sebelum mengikuti senam yoga tertawa adalah sebagian besar informan menyatakan penyakit yang diderita merupakan penyakit yang serius. Sebagaimana pernyataan informan sebagai berikut :

"Ya serius, karena sakit cemas atau pikiran nike yen sing diobati bakalan setres nanti... (I-1)"

Berdasarkan analisis peneliti, dari beberapa penyakit yang diderita lansia mengikuti senam yoga tertawa seperti susah tidur, sakit kepala, jantung, cemas dan hipertensi. Dari penyakit tersebut, lansia menunjukan rasa kehawatiran terhadap sakit yang diderita. Lansia berpandangan bahwa penyakit-penyakit tersebut merupakan penyakit yang serius. Dapat dilihat bahwa, keseriusan penyakit akan mempengaruhi perilaku seseorang. Keseriusan sakit yang dirasakan lansia berdampak terhadap tindakan lansia mengikuti senam yoga tertawa. Dalam (Taylor, 2006) menyebutkan, individu melakukan perilaku sehat tertentu tergantung pada 2 faktor yaitu apakah individu merasakan ancaman yang serius tentang kesehatan dan apakah individu meyakini bahwa perilaku tertentu secara efektif dapat mengurangi ancaman yang dirasakan.

\section{Persepsi kerentanan terhadap penyakit}

Persepsi informan baik laki-laki maupun perempuan terhadap kerentanan terkena penyakit di usia lansia adalah sebagian besar informan menyatakan rentan rentan terkena penyakit. Sebagaiman pernyataan informan sebagai berikut :

"Kalau usia tiyang kan wajar. Karena umur tiyang hampir 70 tahun...(I-1)". 
Berdasarkan hasil FGD baik laki-laki maupun perempuan memandang bahwa usia akan memberikan dampak terhadap karentanan terhadap suatu penyakit. Mereka menyebutkan di usia yang sekarang (60 tahun keatas) sangat rentan untuk terkena penyakit. Dapat dilihat bahwa, kerentanan tubuh seseorang terhadap suatu penyakit dipengaruhi usia individu itu sendiri. Dengan bertambahnya usia terutama pada saat lansia akan terjadi perubahan fungsi tubuh seiring waktu yang terjadi pada sebagian besar mahluk hidup, yang ditandai dengan kelemahan dan meningkatnya kerentanan terhadap suatu penyakit.

Persepsi tentang manfaat yang dirasakan

Manfaat yang dirasakan selama mengikuti senam yoga tertawa adalah informan merasa sehat, sembuh dari penyakit, diringankan sakitnya, sudah bisa tidur. Dari keseluruhan informan laki-laki, semua informan menyatakan hal yang sama, yakni merasa sehat dan sudah bisa tidur. Sebagaimana pernyataan informan sebagai berikut :

"Dengan saya ikut disini senam tertawa dan melupakan segalanya tanpa batas karena pada waktu itu saya senam satu setengah jam dan menimbulkan input yang luar biasa dan saya sampai setelah senam ketawa, sehat dan tidurnya lelap...(I-4)".

Berdasarkan hasil penelitian, pada lansia laki-laki yang sebagian besar menyatakan sakit gangguan tidur, merasakan manfaat setelah mengikuti senam yoga tertawa yakni sudah bisa tidur. Kondisi yang sama terjadi di Unit Pelaksana Teknis Pelayanan Sosial Lanjut Usia, Jember. Dimana dari hasil penelitian (Ananta, 2016) menunjukan manfaat terapi tertawa. Dari jumlah lansia laki-laki sebelum diberikan terapi tawa pada kelompok terapi yaitu sembilan orang dengan persentase kualitas tidur buruk yaitu 100\% dan jumlah lansia perempuan yaitu enam orang dengan persentase kualitas tidur buruk yaitu 100\%. Setelah diberikan terapi tawa persentase kualitas tidur lansia laki yaitu baik sebesar $100 \%$, dan kualitas tidur lansia perempuan yaitu baik sebesar $100 \%$ berarti kualitas tidur lansia laki-laki dan perempuan pada kelompok terapi setelah diberikan terapi tawa mengalami peningkatan. Sehingga memang benar manfaat dari senam yoga tertawa adalah dapat meringankan sakit, salah satunya sakit gangguan tidur.

Motivasi dalam mengikuti senam yoga tertawa

Didapatkan bahwa sebagian besar informan baik laki-laki maupun perempuan menyatakan motivasi dalam mengikuti senam yoga tertawa adalah informan terdorong untuk ingin sembuh, dan menjadi lebih sehat. Sebagaimana pernyataan informan sebagai berikut :

"Ya memang biar sembuh, biar gampang tidur...(I-5)"

Dari hasil penelitian, sebagian besar motivasi lansia mengikuti senam yoga tertawa baik laki-laki maupun perempuan menunjukan bahwa, mereka termotivasi dari diri sendiri. Mereka menyebutkan bahwa termotivasi karena ingin sembuh dan lebih sehat. Menurut (Notoatmodjo, 2007) salah satu fungsi motivasi yaitu mendorong manusia untuk berbuat, sebagai penggerak atau motor yang melepaskan energi. Motivasi dalam hal ini merupakan motor penggerak dari setiap kegiatan yang akan dikerjakan. Motivasi lansia akan 
mempengaruhi tindakan lansia mengikuti senam yoga tertawa.

Bentuk dukungan keluarga

Bentuk dukungan keluarga yang didapatkan oleh informan laki-laki dalam mengikuti senam yoga tertawa adalah sebagian besar menyatakan didukung dengan diingatkan jadwal. Sebagaimana pernyataan informan sebagai berikut :

"Dukungan keluarga sangat mendukung. Jadi kalau saya jadwalnya udah diingetin. Matras juga disiapin sama mantu gitu...(I-5)“.

Selain termotivasi untuk sehat dan sembuh dari sakit, dengan adanya dukungan dari keluarga juga akan memotivasi lansia untuk mengikuti senam yoga tertawa. Sebagian besar menyatakan adanya dukungan dari keluarga. Bentuk dukungan yang diberikan keluarga yaitu dengan mengingatkan jadwal. Dalam hal ini tidak hanya motivasi dari diri sendiri, melainkan bentuk dukungan keluarga juga akan mempengaruhi tindakan lansia. Menurut Setiadi (2008) dalam bukunya yang berjudul "Konsep dan Proses Keperawatan Keluarga" mendefinisikan keluarga adalah bagian dari masyarakat yang peranannya sangat penting untuk membentuk kebudayaan yang sehat. Dengan diingatkan jadwal senam yoga tertawa, akan mempengaruhi lansia untuk mengikuti senam yoga tertawa secara rutin.

Persepsi tentang hambatan yang dirasakan

Sebagian besar informan baik lakilaki maupun perempuan tidak mengalami hambatan dalam mengikuti senam yoga tertawa. Sebagaiman pernyataan informan sebagai berikut :
"Sama sekali tidak. Bahkan ketergantungan. Kalau tidak yoga rasanya kurang enak. Ada yang kurang, ketergantungan sekali...(I-6)".

Berdasarkan hasil penelitian, diketahui bahwa tidak ada alasan yang berarti untuk tidak datang mengikuti senam yoga tertawa. Sebagian besar dari mereka menyatakan tidak ada hambatan dalam mengikuti senam yoga tertawa. Namun, sebagian kecil menyatakan ada hambatan kesibukan dan rasa malas. Dalam hal ini, mereka menganggap motivasi untuk sehat dan sembuh dari penyakit lebih besar pengaruhnya dibandingkan hambatan yang dirasakan. Sehingga hambatan-hambatan tidak mempengaruhi lansia untuk hadir mengikuti senam yoga tertawa.

\section{KETERBATASAN PENELITIAN}

Pada pelaksanaan diskusi kelompok terarah terdapat informan yang masih pasif dalam memberikan pernyataan.

\section{SIMPULAN}

1. Persepsi kerentanan, lansia memandang di usia sekarang rentan terkena penyakit, dikarenakan kondisi dan fungsi tubuh semakin melemah.

2. Persepsi keseriusan terhadap penyakit, lansia memandang penyakit yang diderita adalah serius. Penyakit yang dialami antara lain susah tidur, sakit kepala, sakit jantung, rasa cemas, hipertensi dan rasa bingung.

3. Manfaat yang dirasakan lansia mengikuti senam yoga tertawa adalah merasa lebih sehat, sudah bisa tidur, penyakit diringankan, rasa jenuh hilang dan menjadi lebih rileksasi. 
4. Tidak ada hambatan yang dialami lansia dalam mengikuti senam yoga tertawa.

5. Lansia mengikuti senam yoga tertawa didorong atas keinginan untuk sembuh dan menjadi lebih sehat.

6. Faktor internal yang mendorong lansia mengikuti senam yoga tertawa adalah ingin sembuh dan menjadi lebih sehat. Faktor eksternal antara lain dukungan dari keluarga.

\section{SARAN}

Senam yoga tertawa dapat diterapkan sebagai alternatif untuk membantu lansia dalam mengatasi masalah kesehatan. Puskesmas dapat mengadopsi untuk kegiatan posyandu lansia.

\section{DAFTAR PUSTAKA}

Ananta. (2016). Pengaruh Terapi Tertawa Terhadap Kualitas Tidur Lansia Di Unit Pelaksana Teknis Pelayanan Sosial Lanjut Usia (UPT PSLU) Kabupaten Jember. Jember: Universitas Jember.

Anggun, H. (2011). Pengaruh Penerapan Terapi Tawa Terhadap Penurunan Tingkat Stres Kerja Pada Pegawai Kereta Api. Semarang: Fakultas Psikologi Universitas Diponegoro.

Azizah. (2011). Keperawatan Lanjut Usia. Yogyakarta: Graha Ilmu.

Donny. 2005. Fenomenologi dan Hermeneutika: sebuah

Perbandingan.
Esterina. (2011). Pengaruh Pelatihan Tawa Terhadap Penurunan Tingkat Stres Pada Lanjut Usia (LANSIA) yang Tinggal Di Panti Werdha Hargo Dedali. Surabaya: Fakultas Psikologi Universitas Airlangga Surabaya.

Ika. (2014). Pengaruh Pemberian Terapi Tertawa Terhadap Kejadian Insomnia Pada Usia Lanjut Di PSTW Yogyakarta Unit Budi Luhur. Yogyakarta: Sekolah Tinggi Ilmu Kesehatan 'Aisyiyah Yogyakarta.

Notoatmodjo. (2007). Promosi Kesehatan Teori dan Aplikasi. Jakarta: Rineka Cipta.

Setiadi. (2008). Konsep dan Proses Keperawatan Keluarga.

Taylor, S.E. (2006) Health Psychology (6th Ed), Singapore: Mc. Graw Hill Book Company.

Trifonia. (2015). Efektivitas Terapi Tertawa Untuk Menurunkan Tingkat Depresi Pada Lanjut Usia. Surabaya: Fakultas Kesehatan Masyarakat Universitas Airlangga Surabaya.

WHO. (2015). Lansia di Indonesia. http://www.skripsi.co.id pdf. Diakses pada 28 Januari 2017. 